\title{
Effect of nutrient levels and nutrient schedules on physiological parameters and grain yield of upland rice intercropped in coconut garden
}

\section{B.M.Suman}

Department of Agronomy, College of Agriculture, Kerala Agricultural University, Vellayani695522 (Thiruvananthapuram), India

\section{Sheeja K Raj*}

Kerala Agricultural University, Coconut Research Station, Balaramapuram-695501 (Thiruvananthapuram), India

\section{K Prathapan}

Kerala Agricultural University, Coconut Research Station, Balaramapuram-695501 (Thiruvananthapuram), India

\section{Elizabeth K Syriac}

Department of Agronomy, College of Agriculture, Kerala Agricultural University, Vellayani695522 (Thiruvananthapuram), India

\section{N.V. Radhakrishnan}

Kerala Agricultural University, Coconut Research Station, Balaramapuram-695501 (Thiruvananthapuram), India

*Corresponding author. E-mail: sheejakraj70@gmail.com

\begin{abstract}
The experiment was conducted at Coconut Research Station, Balaramapuram with an objective to study the effect of nutrient levels and nutrient schedules on physiological parameters and grain yield of upland rice (MO 21- Prathyasa rice variety) intercropped in coconut. Field experiment was conducted in factorial randomized block design with nutrient levels as first factor and nutrient schedules as second factor in three replications. Nutrient levels had significant effect on the physiological parameters. Among the nutrient levels rested, NPK applied @ 120:30:60 recorded higher total chlorophyll $\left(2.803 \mathrm{mg} \mathrm{g}^{-1}\right)$ and chlorophyll b content $\left(1.508 \mathrm{mg} \mathrm{g}^{-1}\right)$, crop growth rate (CGR) $\left(11.23 \mathrm{~g} \mathrm{~m}^{-2} \mathrm{day}^{-1}\right.$ ) and relative growth rate (RGR) $\left(0.056 \mathrm{~g} \mathrm{~g}^{-1}\right.$ day $\left.^{-1}\right)$ as compared to lower nutrient level tested, NPK @ 60:30:30 kg ha ${ }^{-1}$. Nutrient schedules also had significant effect $(P=0.05)$ on the physiological parameters viz., total chlorophyll, chlorophyll a, chlorophyll b, CGR and RGR and the treatment receiving 0.2 per cent zinc sulphate and 0.04 per cent sodium borate spray at 45 DAS recorded higher chlorophyll content, RGR and CGR. Though the higher nutrient level, NPK @ 120:30:45 kg ha-1 recorded higher values for physiological parameters, it recorded the lowest grain yield. Application of NPK @ 90:30:45 kg ha-1 recorded the highest grain yield and it was followed by NPK applied @ 70:30:35 kg ha-1. Among the nutrient schedules, $\mathrm{N}$ applied as three equal splits, $\mathrm{P}$ as basal and $\mathrm{K}$ in two equal splits along with foliar spray of zinc sulphate 0.2 per cent and sodium borate 0.04 per cent at 45 DAS recorded the highest grain yield $\left(3.25 \mathrm{t} \mathrm{ha}^{-1}\right)$. The study clearly revealed that excessive vegetative growth is not a desirable parameter for higher grain yield.
\end{abstract}

Keywords: Chlorophyll content, Crop growth rate, Grain yield, Relative growth rate, Upland rice

\section{INTRODUCTION}

Rice provides food for more than 65 per cent of the people living in India and is cultivated in an area of 433.88 lakh ha with an annual production of $104.32 \mathrm{~m} \mathrm{t}$ and productivity of $2404 \mathrm{~kg} \mathrm{ha}^{-1}$ (GOI, 2017). In the recent years the rice production shows a declining trend. Recent research findings revealed that, the production potential of rice can be enhanced by enhancing the area un-

\section{Article Info}

DOI:10.31018/jans.v10i3.1822

Received: July 9, 2018

Revised: July 21, 2018

Accepted: August 7, 2018

\section{How to Cite}

Suman, B.M. et al. (2018).

Effect of nutrient levels and nutrient schedules on physiological parameters and grain yield of upland rice intercropped in coconut garden. Journal of Applied and Natural Science, 10(3): $964-970$ 
development depend solely on applied nitrogen (BRRI, 1997). Nitrogen is vital due to its multidimensional roles in plant growth and metabolism. It is the integral part of chlorophyll, amino acids and genetic material i.e. DNA and RNA (Nawaz et al., 2017). Potassium plays an indispensable role in photosynthesis, activation of enzymes, synthesis of proteins, osmotic potential and as a counter ion to biopolymers (Marschner, 1995). It is required by plants throughout the crop growth but with varying intensity, acute shortage during critical stages are detrimental to the crop growth and yield (Elrewainy et al., 2011). The micronutrients, $\mathrm{Zn}$ and $\mathrm{B}$ play a major role in various plant metabolic activities.

Nitrogen fertilization increased the chlorophyll content and leaf surface area resulted in increased photosynthetic process (Dikshit and Paliwal,1989). Pramanik and Bera (2013) reported that total chlorophyll content gradually increased with the increase in N levels from zero to $200 \mathrm{~kg}$ $\mathrm{ha}^{-1}$. Abou-Khalifa (2012) reported that higher doses of $\mathrm{N}$ (165 and $220 \mathrm{~kg} \mathrm{ha}^{-1}$ ) recorded higher chlorophyll content compared to lower doses (55 and $111 \mathrm{~kg}$ ha-1. Thakur and Patel (1999) reported that crop growth rate (CGR) increased with increase in N level. Sarkar et al. (2001) observed that $\mathrm{N}$ applied @ $150 \mathrm{~kg} \mathrm{ha}{ }^{-1}$ recorded higher CGR at all stages of observation compared to lower $\mathrm{N}$ levels $\left(30,60,90\right.$ and $\left.120 \mathrm{~kg} \mathrm{ha}^{-1}\right)$. However, higher relative growth rate (RGR) was recorded in $\mathrm{N}$ level, $120 \mathrm{~kg} \mathrm{ha}^{-1}$.

Potassium deficiency decreases the photosynthetic rate and reduces the grain yield (Ding et al., 2006). Potassium applied @ $50 \mathrm{~kg} \mathrm{ha}^{-1}$ recorded higher chlorophyll content, CGR, RGR and net assimilation rate (NAR) (Muthukumararaja et al., 2009). Elrewainy et al. (2011) revealed that application of $\mathrm{K}$ in three splits (50 per cent as basal and 25 per cent each at panicle initiation and late booting stage) recorded higher values of total chlorophyll content. Potassium application significantly increased the chlorophyll content both under aerobic and anaerobic conditions (Wakeel et al., 2017).

$\mathrm{Li}$ et al. (1999) reported that chlorophyll content was significantly decreased due to $\mathrm{Zn}$ deficiency. Aravind and Prasad (2004) indicated that $\mathrm{Zn}$ is involved in chlorophyll formation through regulation of nutrients homeostasis in cytoplasm. Mustafa et al. (2011) revealed that the CGR was significantly influenced by zinc nutrition. The maximum CGR and total chlorophyll content were registered with the combined application of borax (7.5 $\mathrm{kg} \mathrm{ha}^{-1}$ ) and zinc sulphate (12.5 kg ha-1) (Sarwar et al., 2013). Chlorophyll content is increased by the application of B and Zn (Pervaiz et al., 2012). Rehman et al. (2014) reported that foliar spray of $0.16 \mathrm{M} \mathrm{B}$ and $0.24 \mathrm{M} \mathrm{B}$ recorded higher total chlorophyll contents in rice varieties Super basmati

\section{and Shaheen basmati.}

With this background, a field experiment was conducted at Coconut Research Station, Balaramapuram with an objective to study the effect of nutrient levels and nutrient schedules on the total chlorophyll, chlorophyll a and b content, crop growth rate, relative growth rate and yield of upland rice (MO 21- Prathyasa rice variety) intercropped in coconut.

\section{MATERIALS AND METHODS}

Experiment was conducted at Coconut Research Station Balaramapuram in a coconut plantation planted with WCT (West Coast Tall) at a spacing of $7.5 \times 7.5 \mathrm{~m}$ having more than 55 years old. The experimental site was located at $8^{\circ} 22^{\prime} 52^{\prime \prime}$ North latitude and $77^{\circ} 1$ ' $47^{\prime \prime}$ East longitude and at an altitude of $9 \mathrm{~m}$ above mean sea level. The soil was sandy clay loam in texture, acidic in reaction (soil pH 4.5), medium in organic carbon ( 0.75 per cent), high in phosphorous (27.2 $\left.\mathrm{kg} \mathrm{ha}^{-1}\right)$, medium in potassium (128.5 kg ha $\left.{ }^{-1}\right)$, sufficient in $\mathrm{Zn}$ $\left(1.120 \mathrm{mg} \mathrm{kg}^{-1}\right.$ soil) and deficient in $B\left(0.08 \mathrm{mg} \mathrm{kg}^{-}\right.$ soil). The experiment was laid out in factorial RBD with two factors, the first factor comprised of four different nutrient levels viz., $\mathrm{n}_{1}-\mathrm{NPK} @$

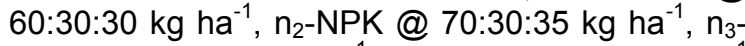
NPK @ 90:30:45 kg ha-1 and $\mathrm{n}_{4^{-}}$120:30:60 kg haand the second factor comprised of four different nutrient schedules, viz., $\mathrm{s}_{1}-\mathrm{N}$ in three equal splits (at 15 DAS, active tillering and panicle initiation stage), $\mathrm{P}$ as basal and $\mathrm{K}$ in two equal splits (at 15 DAS and panicle initiation stage), $\mathrm{S}_{2}-\mathrm{N}$ in three equal splits (at 15 DAS, active tillering and panicle initiation stage), $\mathrm{P}$ as basal and $\mathrm{K}$ in three equal splits (at 15 DAS, active tillering and panicle initiation stage), $s_{3}-s_{1}+$ foliar spray of zinc sulphate at 0.2 per cent and sodium borate at 0.04 per cent, $\mathrm{s}_{4}-\mathrm{s}_{2}+$ foliar spray of zinc sulphate at 0.2 per cent and sodium borate at 0.04 per cent. The variety used for the study was Prathyasa (MO 21), a short duration variety released from Rice Research Station, Moncompu. Method of sowing adopted was dibbling at a spacing of $20 \mathrm{~cm} \times 10 \mathrm{~cm}$. Seed rate adopted was $80 \mathrm{~kg} \mathrm{ha}^{-1}$. The entire dose of $P$ was applied in the form of rock phosphate just before sowing the seeds. $\mathrm{N}$ and $\mathrm{K}$ were applied in the form of urea and muriate of potash as per the treatment schedules. Zinc sulphate and sodium borate were applied as the treatment schedule at 45 DAS. Total chlorophyll content, chlorophyll a and $b$ content were determined at 60 DAS as per the procedure suggested by Yoshida et al., 1976. The crop growth rate was determined at 40-60 DAS by the method suggested by Evans, 1972 and crop growth rate was determined at 40-60 DAS by the method described by Watson, 1958. The grain harvested from the net plot area was sun dried to 14 per cent moisture content, the grain weight was recorded and expressed in tha ${ }^{-1}$. 
The data were analyzed statistically by using Analysis of Variance technique for RBD. The significance was tested using $F$ test and whenever, the $F$ values were found significant, critical difference was calculated at $5 \%$ probability level.

\section{RESULTS AND DISCUSSION}

Effect of nutrient levels and schedule of nutrient application on Total chlorophyll and b content: Nutrient levels significantly influenced the total chlorophyll content and chlorophyll b content at 60 DAS but did not have any significant effect on chlorophyll a content (Table 1). Results revealed that compared to $n_{1}$ (NPK @ 60:30:30 kg ha $\left.^{-1}\right)$, the other three levels i.e., NPK @ 70:30:35, 90:30:45 and 120:30:60 kg ha ${ }^{-1}\left(\mathrm{n}_{2}, \mathrm{n}_{3}\right.$ and $\left.\mathrm{n}_{4}\right)$ recorded higher total chlorophyll, chlorophyll a and $b$. High chlorophyll content registered in the treatments, $\mathrm{n}_{2}, \mathrm{n}_{3}$ and $\mathrm{n}_{4}$ might be due to higher photosynthetic area resulting from higher number of tillers $\mathrm{m}^{-2}$. The increased rate of application of $\mathrm{N}$ and $\mathrm{K}$ in these treatments might have enhanced the $\mathrm{N}$ and $\mathrm{K}$ uptake which in turn increased the $\mathrm{N}$ and $\mathrm{K}$ content in leaves. $\mathrm{N}$ being the structural constituent of nucleic acid, proteins, amino acids and chlorophyll molecule affects the formation of chloroplast and accumulation of chlorophyll in them (Daughtry et al., 2000; Tucker, 2004). Very close linear relation exists between $\mathrm{N}$ content and chlorophyll content (Bojovic and Markovic, 2009). Hence rice crop grown on soil with sufficient amount of $\mathrm{N}$ showed a rapid vegetative growth with high chlorophyll content (Kumar et al., 2015). Pramanik and Bera (2013) observed that application of $\mathrm{N}$ at higher doses recorded higher chlorophyll content compared to lower doses in hybrid rice. The Li et al. (2012) also observed 12 per cent increase in chlorophyll content in rice leaves, when rice seedlings were fed with high nitrogen. Potassium also plays a vital role in the synthesis of chlorophyll by taking part in various enzymatic reactions necessary for such building up process (Evans and Sorger, 1966). Krishnapillai and Ediriweera (1986) reported that the $\mathrm{K}$ application rate increased from 70 to $140 \mathrm{~kg} \mathrm{ha}^{-1}$, the chlorophyll content of tea leaves was also found to increase. Wakeel et al. (2017) also pointed out that in aerobic and flooded rice the highest chlorophyll content of leaves was observed in treatment receiving $\mathrm{K} @ 180 \mathrm{~kg} \mathrm{ha}^{-1}$ compared to lower dose, $90 \mathrm{~kg}$ ha $^{-1}$.

Nutrient schedules also significantly influenced the chlorophyll content. Among the different schedules, the treatments with the foliar spray of zinc sulphate and sodium borate $\left(s_{3}\right.$ and $\left.s_{4}\right)$ recorded higher chlorophyll $a, b$ and total chlorophyll. Higher leaf production and tiller $\mathrm{m}^{-2}$ increased the chlorophyll production in these treatments. Samreen et al. (2013) pointed out that higher leaf area resulting from the increase in length and

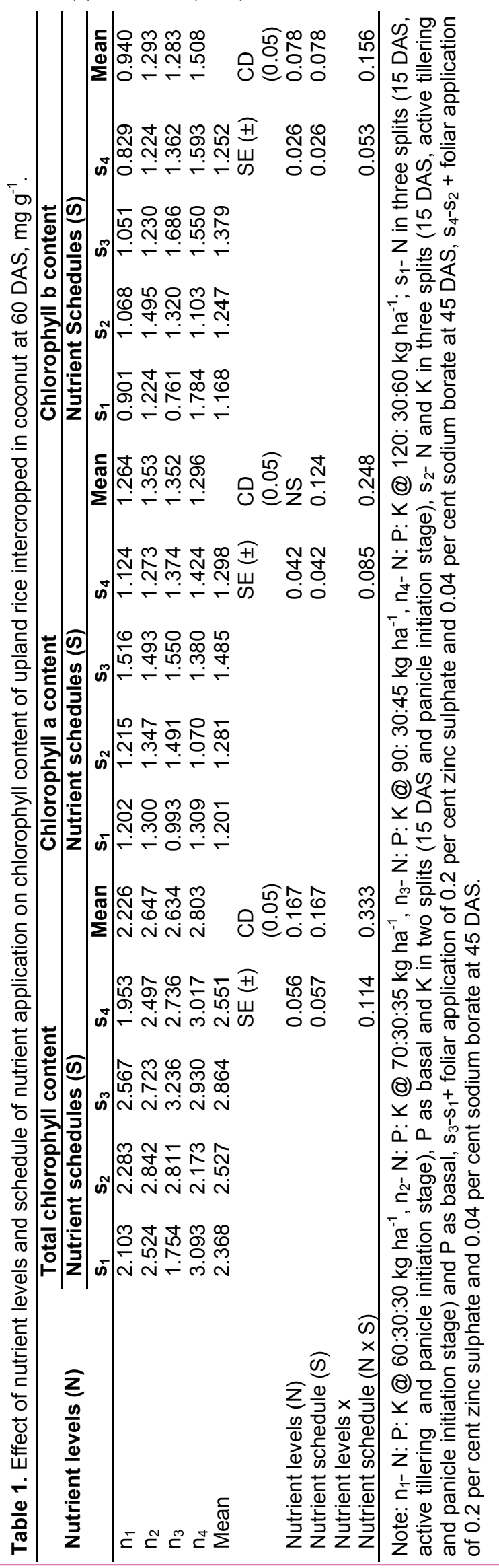




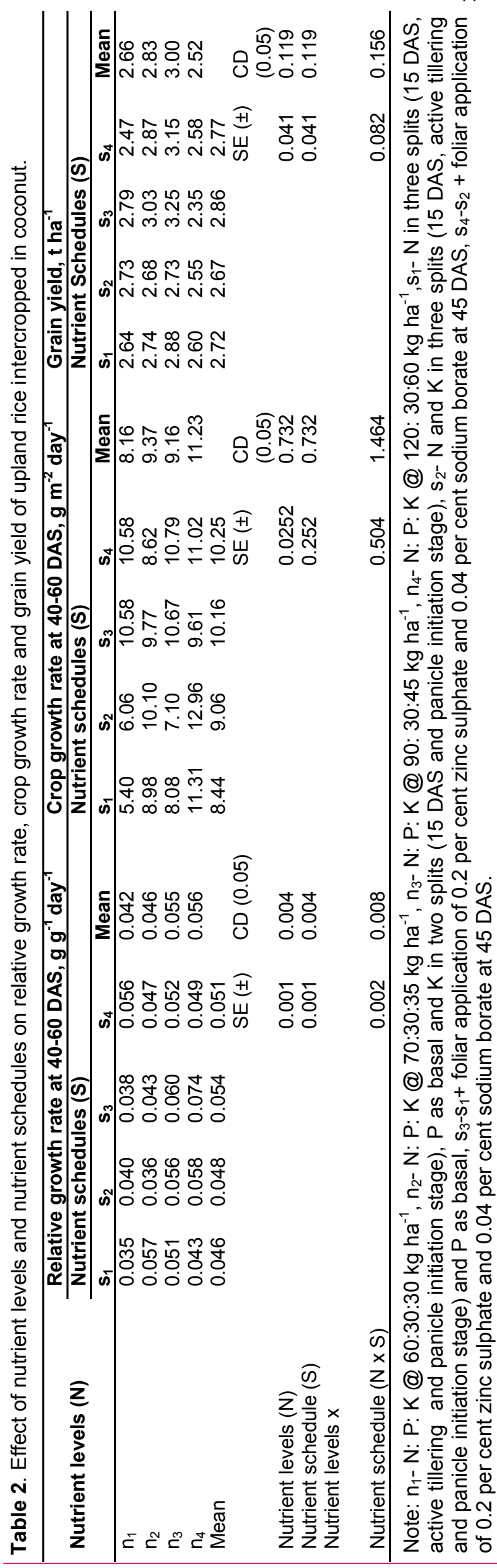

breadth of the leaf of mung plant increases the chlorophyll production. Foliar application of $\mathrm{Zn}$ and $B$ increased the photosynthesis and chlorophyll production in rice (Pervaiz et al., 2014), maize (Tariq et al., 2014) and in gladiolus (Fahad et al., 2014). Though, $\mathrm{Zn}$ is not directly involved in chlorophyll synthesis it plays a pivotal role in the availability of $\mathrm{N}$ and $\mathrm{Mg}$, the major constituents in the molecular structure of chlorophyll. Ayad et al. (2010) reported that $\mathrm{Zn}$ played a crucial role in triggering some of the chlorophyll biosynthetic pathway enzymes. Mathpal et al. (2015) opined that $\mathrm{Zn}$ fertilization resulted in considerable increase in total chlorophyll, chlorophyll $a$ and $b$ content in rice leaves. Boron fertilization caused significant enhancement in total chlorophyll content and photosynthetic rate of pea nut plant (Nasef et al., 2006).

The treatment combination $\mathrm{n}_{3} \mathrm{~s}_{3}$ (NPK @ 90:30:45 $\mathrm{kg} \mathrm{ha}^{-1}$ applied as $\mathrm{N}$ in three equal splits, $\mathrm{P}$ as basal and $\mathrm{K}$ in two equal splits along with foliar spray of 0.2 per cent zinc sulphate and 0.04 per cent sodium borate at 45 DAS) recorded the highest total chlorophyll $\left(3.236 \mathrm{mg} \mathrm{g}^{-1}\right)$, chlorophyll a $\left(1.550 \mathrm{mg} \mathrm{g}^{-1}\right)$ and chlorophyll b content (1.686 $\mathrm{mg} \mathrm{g}^{-1}$ ) at 60 DAS. This might be due to higher uptake of $\mathrm{N}$, enhanced photosynthesis and also due to the favourable influence of $\mathrm{Zn}$ and $\mathrm{B}$ on the chlorophyll formation.

Effect of nutrient levels and schedule of nutrient application on relative growth rate and crop growth rate at 40-60 DAS: The crop growth rate (CGR) and relative growth (RGR) rate were significantly influenced by the nutrient levels (Table 2). It has been observed from the results that treatments receiving higher levels of $\mathrm{N}$ and $\mathrm{K}$ $\left(\mathrm{n}_{4}, \mathrm{n}_{3}, \mathrm{n}_{2}\right)$ recorded higher RGR and CGR at 4060 DAS might be due to higher chlorophyll content (Table 1) and LAI which leads to more dry matter production. Nitrogen being the structural constituent of chlorophyll, its application increased the chlorophyll content and leaf surface area which in turn increases the crop growth rate. Potassium application also enhanced the leaf area and DMP due to the active role in photosynthesis, cell growth, osmotic adjustment, stomatal regulation, transport of photosynthates from leaf into phloem, transportation within the cow pea plant and also anion-cation balance (Motaghi and Nejad, 2014). Hassan et al. (2007) and Rajesh et al. (2017) revealed that low levels of $\mathrm{N}$ reduced the photosynthesis process, leaf chlorophyll content and crop growth rate in rice. Motaghi and Nejad (2014) in their studies on the effect of different levels of $\mathrm{K}$ on physiological indices of crop growth in cow pea plant revealed that CGR and RGR increased with increase in K level. Wakeel et al. (2017) pointed out that K applied @ 180 kg ha ${ }^{-1}$ significantly improved the total biomass production of rice cultivar Super basmati compared to $90 \mathrm{~kg} \mathrm{ha}^{-1}$ under aero- 
bic system of rice cultivation.

Nutrient schedules significantly influenced the CGR and RGR at 40-60 DAS. The treatments with the foliar application of zinc sulphate and sodium borate recorded higher CGR and RGR values at 40-60 DAS. The increase in CGR and RGR values observed in these treatments might be due to more biomass production resulting from higher LAI and total chlorophyll content (Table 1). Foliar application of $\mathrm{Zn}$ and $\mathrm{B}$ in these treatments resulted in higher dry matter production due to their active role in physiological processes like stomatal regulation, chlorophyll formation, enzyme activation and biochemical processes in wheat plant (Cakmak, 2008 and Khan et al., 2010) and in higher plants (Marschner, 2012).

In the present study, the interaction between nutrient levels and nutrient schedules was also found significant. The treatment, $\mathrm{n}_{4} \mathrm{~s}_{2}$ (NPK @ 120:30:60 $\mathrm{kg} \mathrm{ha}^{-1}$ applied as $\mathrm{N}$ in three equal splits, $\mathrm{P}$ as basal and $\mathrm{K}$ in three equal splits and $\mathrm{n}_{4} \mathrm{~s}_{3}$ (NPK @ $120: 30: 60 \mathrm{~kg} \mathrm{ha}^{-1}$ applied as $\mathrm{N}$ in three equal splits, $\mathrm{P}$ as basal and $\mathrm{K}$ in two equal splits along with foliar spray of 0.2 per cent zinc sulphate and 0.04 per cent sodium borate) recorded higher CGR and RGR, might be due to the favourable influence of higher rate of $\mathrm{N}$ and $\mathrm{K}$ on the vegetative growth of rice as evidenced from data on chlorophyll content (Table 1).

Effect of nutrient levels and schedule of nutrient application on yield attributes and grain yield: Grain yield increased with incremental dose of $\mathrm{N}$ up to $90 \mathrm{~kg} \mathrm{~N}$ and $\mathrm{K}$ up to $45 \mathrm{~kg} \mathrm{~K} \mathrm{ha}^{-1}$. However, decrease in yield was observed at further increase of $\mathrm{N}$ and $\mathrm{K}$ (Table 2). The nutrient level $\mathrm{n}_{3}$ (NPK @ 90:30:45 kg ha-1) recorded significantly higher grain yield $\left(3.00 \mathrm{t} \mathrm{ha}^{-1}\right)$ compared to other nutrient levels and was followed by $\mathrm{n}_{2}$ (NPK @ 70:30:35 kg ha-1). The increased grain yield observed in $n_{3}$ might be due to the increased availability and utilization of $\mathrm{N}$ and $\mathrm{K}$ within the plant resulting from the better expression of physiological parameters (Table 1). Increased dose of $\mathrm{N}$ and $\mathrm{K}$ provided continuous and steady supply of nutrients into the soil solution to match the nutrient requirement of the crop which, consequently resulted in the production of longer panicles with more number of grains panicle ${ }^{-1}$. Mahapatra and Panda (1972) reported that balanced fertilization with $\mathrm{N}, \mathrm{P}$ and $\mathrm{K}$ was essential for higher grain yield in upland rice.

Nutrient schedules significantly influenced the grain yield. It has been observed that foliar spray of zinc sulphate and sodium borate had significant effect on yield. The treatment $s_{3}(\mathrm{~N}$ in three equal splits, $\mathrm{K}$ in two equal splits and $\mathrm{P}$ as basal along with foliar spray of 0.2 per cent zinc sulphate and 0.04 per cent sodium borate at 45 DAS) recorded the highest grain yield and was statistically on par with $\mathrm{S}_{4}(\mathrm{~N}$ and $\mathrm{K}$ in three equal splits and $\mathrm{P}$ as basal along with foliar spray of 0.2 per cent zinc sulphate and 0.04 per cent sodium borate at 45 DAS). Better crop growth enables the crop to absorb and utilize nutrients in a better way might be the reason for higher grain yield in $s_{3}$ and $s_{4}$. Moreover, these treatments also have foliar spray of $\mathrm{Zn}$ and $\mathrm{B}$. Both the micronutrients may have significant effect on grain yield by their role in grain setting and accumulation of carbohydrate in grain. Rehman et al. (2014) revealed that foliar nutrition of $B$ significantly improved the grain yield and yield related parameters of rice.

In the present study, the interaction effect between nutrient levels and nutrient schedules was also found significant $(P=0.05)$. The treatment combination, $n_{3} s_{3}$ (NPK @ 120: 30: 60 kg ha ${ }^{-1}$ applied as $\mathrm{N}$ in three equal splits, $\mathrm{P}$ as basal and $\mathrm{K}$ in two qual splits along with foliar spray of $0.2 \mathrm{per}$ cent zinc sulphate and 0.04 per cent sodium borate at 45 DAS) recorded the highest grain yield. This was owing to the better expression of crop growth factors and yield attributes. Rahman et al. (2008) reported that application of $\mathrm{Zn}$ along with NPK fertilizer enhanced the grain yield of boro rice. Rehman et al. (2014) reported that foliar application $0.32 \mathrm{M} \mathrm{B}$ along with recommended dose of NPK and $\mathrm{Zn}$ enhanced the grain yield of rice.

\section{Conclusion}

Application of higher nutrient levels registered higher chlorophyll content, crop growth rate and relative growth rate of upland rice intercropped in coconut. But, the highest grain yield of rice was registered in the treatment NPK @ 90:30:45 kg ha ${ }^{-1}$ and it was followed by NPK @ 70:30:35 kg ha ${ }^{-1}$ and the lowest grain yield recorded in higher nutrient level, NPK @ 120: 30:60 kg ha ${ }^{-1}$. Among the nutrients schedules, treatment with 0.2 per cent zinc sulphate and 0.04 per cent sodium borate recorded higher chlorophyll content, CGR and RGR and recorded higher grain yield. Hence it can be concluded that, an optimum level of nutrients is required for optimum crop growth and yield. Excessive fertilization resulted in enhanced vegetative growth with-out incremental increase in grain yield. Application of NPK @90:30:45 $\mathrm{kgha}^{-1}$, applied as $\mathrm{N}$ in three equal splits (at 15 DAS, active tillering and panicle initiation), $\mathrm{P}$ as basal and $\mathrm{K}$ in two equal splits (at 15 DAS and panicle initiation was found the optimum dose for optimum crop growth and higher grain yield in upland rice intercropped in coconut.

\section{REFERENCES}

1. Abou-Khalifa, A. A. B. (2012). Evaluation of some rice varieties under different nitrogen levels. Adv. Appl. Sci. Res. 3 (2): 1144-1149.

2. Alagesan, A. and Babu, C. R. (2011). Impact of different nitrogen levels and time of application on grain yield and yield attributes of wet seeded rice. Int. $J$. Food. Agric. Vet. Sci. 1(1): 1-5. 
3. Aravind, P. and Prasad, M.N.V. (2004). Zinc protects chloroplasts and associated photochemical functions in cadmium exposed Ceratophyllum dermesum L., a freshwater macrophyte. Plant Sci. 166: 1321-1327.

4. Ayad, H.S., Reda, F., and Abdalla M.S.A. (2010). Effect of putrescine and zinc on vegetative growth, photosynthetic pigments, lipid peroxidation and essential oil content of geranium (Pelargonium graveolens L.). World J. Agric. Sci. 6: 601-608.

5. BRRI [Bangladesh Rice Research Institute]. (1997). Internal review for 1994. Bangladesh rice research institute. Joydebpur, Gazipur. pp. 7-8.

6. Bojovic, B. and Markovic, A. (2009). Correlation between nitrogen and chlorophyll content in wheat (Triticum aestivum L.). Kragujevac J. Sci. 31: 69-74.

7. Cakmak, I. (2008). Enrichment of cereal grains with zinc: Agronomic or genetic biofortification. Plant Soil. 302: 1-17.

8. Daughtry, C. S. T., Walthall, C. I., Kim, M. S., de Colstoun, B., and McMurtrey, J. E. (2000). Estimating corn leaf chlorophyll concentration from leaf and canopy reflectance. Rem. Sens Environ. 74:229-239

9. Dhanpal, R. (2010). Relevance and oppurtunities in coconut-based cropping/farming systems. In: Thomas, G.V., Krishnakumar, V., Maheshwarappa, H.P. and Palaniswami, C. (eds), Coconut based cropping/ farming systems. Central Plantation Crop Research Institute, Kasargod, pp.1-8.

10.Dikshit, P.R. and Paliwal, A.K. (1989). Effect of nitrogen and sulphur on the yield and quality of rice. Agric. Sci. Digest 9:171-174

11.Ding, Y., Luo, W., and Xu, G. (2006). Characterization of magnesium nutrition and interaction of magnesium and potassium in rice. Ann. Appl. Biol. 149:111-123

12.Evans, G.C. (1972). The Quantitative Analysis of Growth. Oxford: Blackwell Scientific Publications, 295p.

13.Evans, H. J. and Sorger, G. J. (1966). Role of mineral elements with emphasis on the univalent cations. Annu. Rev. Plant Physiol. 17:47-76.

14.Elrewainy, I.M.O., Naeem, E.S., and Mohammed, A.A.A. (2011). Effect of time of and methods of nitrogen and potassium application at different growth stages on hybrid 1 and Giza 178 rice cultivare. Egypt. J. Agron. 33 (2): 113-129.

15.Fahad, S., Ahmad, M., Anjum, M.A., and Hussain, S. (2014). The effect of micronutrients (B, $\mathrm{Zn}$ and $\mathrm{Fe}$ ) foliar application on the growth, flowering and corm production of gladiolus (Gladiolus grandiflorus L.) in calcareous soils. J. Agric. Sci. Technol. 16: 16711682

16.GOI [Government of India, Ministry of Agriculture and Farmers' Welfare]. (2017). Annual Report 20162017. Government of India, Ministry of Agriculture and Framer's Welfare, Krishibhavan, New Delhi,194p.

17.Hassan, M.S., Khair, A., Haque, M.M., and Hamid, A. (2007). Photosynthetic characters, SPAD value and use efficiency of traditional AUS rice (Oryza sativa L.) cultivars. SAARC J. Agric. 5 (2): 29-40.

18.Khan, M.B., Farooq, M., Hussain, M., and Shabir, G. (2010). Foliar application of micronutrients improves the wheat yield and net economic return. Int. J. Agric. Biol. 12: 953-956.

19.Krishnapillai, S. and Ediriweera, V. L. (1986). Influence of levels nitrogen and potassium fertilizers on chlorophyll content in mature clonal tea leaves. Sri
Lanka J. Tea Sci., 55 (2): 71-76.

20.Kumar, N., Mathpal, B., Sharma, A., Shukla, A., Shankdhar, D., and Shankdhar, S.C. (2015). Physiological evaluation of nitrogen use efficiency and yield attributes in rice (Oryza sativa L.) genotypes under different nitrogen levels. Cereal Res. Commun. 43 (1): 166-177.

21.Li, Y., Yang, X., Ren, B., Shen, Q., and Guo, S. (2012). Why nitrogen use efficiency decreases under high nitrogen supply in rice (Oryza sativa L.) seedlings. J. Plant Growth Reg. 31: 47-52.

22.Li., Yan., Qin., Suichu., Li, Y., and Qin, S.C. (1999). Effect of rice metabolism and the diagnosis of hidden zinc deficiency in rice. J. Fujian Agric. Univ. 28(1):66-67

23.Mahapatra, I.C. and Panda, S.C. (1972). Uptake and utilization of nitrogen, phosphorus and potassium by dwarf Indica rice. Rice Newsl. 21: 1-19.

24.Marschner, H. (1995). Mineral Nutrition of Higher Plants ( $2^{\text {nd }} E d$.) UK Academic Press, London, 889p.

25.Marschner, P. (2012). Marschner's Mineral Nutritional of Higher Plants ( $3^{\text {rd }}$ Ed.). Academic Press, London, UK, pp. 135-189.

26.Mathpal, B., Srivastava, P.C., Shankdhar, D., and Shankhdhar, S.C. (2015). Improving key enzyme activities and quality of rice under various methods of zinc application. Physiol. Mol. Biol. Plants. 21(4):567-572

27.Mustafa, G., Enshanullah., Akbar, N., Qaisrani, S.A., Iqbal, A., Khan, Z.H., Jabran, K., Chattha, A.A., Trethowan, R., Chattha, T., and Atta, B.M. (2011). Effect of zinc application on growth and yield of rice. Int. J. Agro Vet. Med. Sci. 5 (6): 530-535.

28.Muthukumararaja, T., Sriramachandrasekharan, M.V., and Ravichandran. (2009). Growth and sink potential of rice as influenced by sulphur and potassium fertilization. Plant Arch. 9: 83-85.

29.Motaghi, S. and Nejad, T.S. (2014). Effect of different levels of humic acid and potassium fertilizer on physiological indices of growth. Int. J. Biosci. 5 (2): 99-105.

30.Nasef, M. A., Badran, N. M. and Abd El-Hamide, A. F.( 2006). Response of peanut to foliar spray with boron and/or rhizobium inoculation. J. Appl. Sci. Res. 2: 1330-1337.

31.Nawaz, M., Wahla, A.J., Kashif, M.S., Waqar, M.Q., Ali, M.A., and Chadhar, A.R. (2017). Effect of exogenous nitrogen levels on the yield of rice grain in Sheikhpura, Pakistan. Pakist. J. Agric. Res. 30 (1): 85-92.

32.Nelliat, E.V. (1979). Prospects of multiple cropping in coconut-based farming system- The Indian Experience- Technical Bulletin, Indian Council for Agricultural Research, India, 43p.

33.Pervaiz, K., Yousuf, M., Imtiaz, M., Depar, M., Aslam, M., Suleman., and Javed, A.S. (2012). Determining the zinc requirements of rice genotype sarshar evolved at NIA, Tandojam. Sarhad J. Agric. 28(1):1-7

34.Pramanik, K. and Bera, A.K. (2013). Effect of seedling age and nitrogen fertilizer on growth, chlorophyll content and economics of hybrid rice (Oryza sativa L.). Int. J. Agron. Plant Prot. 4 (5): 3489-3499. Retrieved May 012018 from http:/l www.ijappjournal.com

35.Rahman, M.T., Jahiruddin, M., Humauan, M.R., Alam, J.M., and Khan, A. A. (2008). Effect of sulphur and zinc on growth, yield and nutrient uptake of boro rice (CV. BRRI dhan 29). J. soil. Nat. 2 (3): 10-15. 
36.Rajesh, K., Thatikunta, R., Naik, D.S., and Arunakumari, J. (2017). Effect of different nitrogen levels on morpho physiological and yield parameters in rice (Oryza sativa L.). Int. J. Curr. App. Sci. 6 (8): 22272240.

37.Rehman, A., Farooq, M., Cheema, Z.A., Nawaz, A., and Wahid, A. (2014). Foliage applied boron improves the panicle fertility, yield and biofortification of fine grain aromatic rice.J. of Soil Sci. and Plant. Nutr. 14 (3): 723-733.

38.Samreen, T., Shah, H.U., Ullah, S., and Javid, M. (2013). Zinc effect on growth rate, chlorophyll, protein and mineral contents of hydroponically grown mung beans plant (Vigna radiata). Arabian $J$ chemic. 7: $145-152$.

39.Sarkar, S., Pal, S., Mandal, N.N., and Maiti, S. (2001). Response of rice cultivars to different levels of nitrogen. Environ. Ecol. 19 (1): 118-120.

40.Sarwar, N., Ali, H., Ahmad, A., Ullah, E., Ahmad, S., Mubeen, K., and Hill, J.E. (2013). Water wise rice cultivation on calcareous soils with the addition of essential micronutrients. J. Anim. Plant. Sci. 23 (1): 244-250.

41. Thakur, D.S. and Patel, S.R.(1999). Growth and sink potential of rice as influenced by the split application of potassium with FYM in inceptisols of eastern centeral India J. of potassium Res. Madhya Pradesh, India. pp. 73-77.

42.Tariq, A., Anjum, S.A., Randhawa, M.A., Ullah, E., Naeem, M., Qamar, R., Ashraf, U., and Nadeem, M. (2014). Influence of zinc nutrition on growth and yield behaviour of maize (Zea mays L.) hybrids. Am. J. Plant. Sci. 5: 2646-2654.

43.Tucker, M. (2004). Primary Nutrients and Plant Growth. - In: Essential Plant Nutrients (Scribed, Ed.). North Carolina Department of Agriculture, USA,pp1-9

44.Wakeel, A., Rehman, H.U., Mubarak., M.U., Dar, A.I., and Farooq, M. (2017). Potash use in aerobic production system for basmati rice may expand its adaptability as an alternative to flooded rice production system. J. Soil Sci. Plant nutr. 17 (2): 398-409.

45.Watson, D.J. (1958). The dependence of net assimilation rate on leaf-area index. Ann. Bot. 22(11):37-54

46. Yoshida, S., Forno, D. O., Cook, J. H. and Gomez, K. A. (1976). Laboratory Manual for Physiological Studies of Rice. International Rice Research Institute, Los Banos, Manila, Philippines, 82p. 